usually monosporous sporangia in the position in which Harvey nearly fifty years ago suggested, and in the cortex too. I hope to publish shortly a detailed description.

\title{
Bigbury Bay.
}

The rocks south of Yealm River mouth towards Stoke Point, fully exposed to the south-west gales, were generally barren like those between Rame Head and Penlee Point. East of Revelstoke Point, and well protected by it, there are good, well-stocked rock-pools. A short visit to the pools west of Revelstoke Church led me to think the weeds generally comparable to those found on the Renny Rocks, Wembury Point, and the Mewstone. Cystoclonium purpurascens, Sarcophyllis edulis, Monospora, Griffithsia equisetifolia, Ptilota elegans, Mesogloea vermiformis, and many others were seen. The dredge brought up Phyllophora rubens with nemathecia, Spondylothamnion multifida, Antithamnion plumula, Bonnemaisonia asparagoides, Dictyopteris polypodioides, Sphacelaria filicina, \&c.

I propose in a subsequent number of the Journal to continue my observations on the flora, to give a more detailed list of the species met with, and to trace out the distribution, in the different localities, of individual species. I have, I trust, said enough to show that there is no lack of algæ needing investigation. It is impossible for me to give an adequate idea of the details of the flora. I shall be only too pleased to place my knowledge, gained under such great advantages, at the service of algologists. 


\title{
Report of a Trawling Cruise in H.M.S. "Research" off the South-west Coast of Ireland.
}

\author{
By
}

\section{Gilbert C. Bourne, M.A., F.L.S.,}

Fellow of New College, Oxford, and Director of the Association.

The cruise, of which the zoological results are given in this report, was undertaken at the suggestion of Capt. Wharton, R.N., F.R.S., hydrographer to the Admiralty, who kindly advised me that H.M.S. "Research" was to make a fresh series of soundings off the entrance to the Channel, and put me in communication with the captain of the ship. To Capt. Aldrich I am indebted for unbounded hospitality and attention whilst I was on board, and I take this opportunity of expressing my most hearty thanks both to him and to the officers on board for the hospitality and kindness which they afforded me, and for the help which they gave me in the trawling operations. The "Research" is a paddle vessel of 520 tons register, built last year for the express purpose of surveying, and provided with a steam winch, deep-sea trawls and dredges, and 1000 fathoms of wire rope, with accumulators and accessory tackle. The available space on board was limited; there was no separate cabin at my disposal, so Capt. Aldrich most kindly made me his guest and gave me a berth in his own cabin, and I was given as much room as could possibly be allowed for storing my bottles and other apparatus.

Having joined the ship at Queenstown, we left the harbour on the evening of Tuesday, July 9th, and stood on a westerly course for Cape Clear. On the 10th, having cleared the Irish coast, the ship's head was turned south, and a line of soundings was made on the edge of the bank which was under survey. During this and the three succeeding days the ship was turned westward for a few hours each day, and the trawl was shot in deep water off the bank. At night we returned to the bank and anchored. On Sunday, July 14th, we remained at anchor at the south-west extremity of the bank, and on Monday we resumed a northerly course on about the meridian of $10^{\circ} 7^{\prime} \mathrm{W}$. longitude, retracing our course on the 18 th to run another line of soundings a little eastward of our previous position. During each of these days the trawl was shot on the bank in from 70 to 80 fathoms. During the expedition I took a number of hauls 
with the tow-net, both in daytime and at night. On the 19th we made for Queenstown, and arrived in port in the evening, after a very enjoyable cruise, during which we were favoured with remarkably fine weather.

A little more than a week previously the Rev. W. Spotswood Green had undertaken a similar cruise in the "Flying Fox," belonging to the Clyde Shipping Company, and had trawled in considerable depths in nearly the same locality as that in which we began our operations, but he kept further north than we did throughout his trip. Being before me both in his cruise and in the date of publishing his results, $\mathrm{Mr}$. Green has rather taken the edge of novelty off my work; but although I must yield the pride of priority to some of his species, which were new, and were taken immediately after by myself, the interest of the trawling in the "Research" is not in reality diminished by this circumstance. In fact, my cruise may be considered as complementary to that of the "Flying Fox," and continued the line of trawling much further south, giving a fuller and more comprehensive view of the bottom fauna of this part of the sea.

Some of the most interesting results of my cruise were the capture of a second specimen of Solea Greenii, Günther, a new species, of which a single specimen only was taken in the "Flying Fox ;" the capture of Macrurus lævis and Rhombus boscii, both new to British fauna before Mr. Green's expedition, and of Haloporphyrus eques, which was not taken by him. I also took several specimens of the rare Asterid, Nymphaster subspinosus, a single specimen of Eupagurus carneus, Pocock, which was first taken by Mr. Green, three fine specimens of Epizoanthus paguriphilus, Verrill, and a new species of the genus Leptothyra.

The general results of the trawling at the different stations are given below, and the list of the species collected is given in a separate table. I undertook to work out the whole collection myself, which has delayed the publication of my report ; but eventually I have had to go to several friends for assistance in some of the groups, and I have received much assistance from Canon A. M. Norman. Professor Jeffrey Bell has kindly given me a separate report on the Echinoderms.

Station 1. July 10th, 1889. Position, $50^{\circ} 50^{\prime} 15^{\prime \prime}$ N., $11^{\circ} 12^{\prime}$ $30^{\prime \prime}$ W.- The trawl was shot at 4 p.m. in 200 fathoms, and was down an hour and a half. The bottom consisted of fine sand, containing many Foraminifera. A large hanl of fish, including many "megrims" (Rhombus boscii), two species of Macrurus (M. lævis and M. coelorhynchus); Haloporphyrus eques, a Phycis, many Scorpæna dactyloptera, and a single large specimen of Raia batis; quantities of Spatangus purpureus and Holothurians (H. tremula), a 
single specimen of Asterias rubens, and a few Actinauge Richardi, with other specimens, among which was a hitherto undescribed species of Leptothyra.

Station 2. July 11th. Position, $50^{\circ} 29^{\prime} 26^{\prime \prime}$ N., $11^{\circ} 4^{\prime}$ W.The trawl was shot at 11 a.m. in 400 fathoms, and was hauled up at 1.12 p.m., taking an hour and twenty-eight minutes in coming to the surface. It contained only one fish, Haloporphyrus eques, a great quantity of Spatangus purpureus, four specimens of Nymphaster subspinosus, multitudes of Echinus norvegicus sticking in the swabs ; several crustacea, including Eupagurus carneus, Lipsognathus Thomsoni, Scyramathia Carpenteri, Bathynectes longispinosa, and Ebalia nux; three specimens of Epizoanthus paguriphilus, and other forms, among which were two or three specimens of Actinauge Richardi.

Station 3. July 12th. Position, $49^{\circ} 50^{\prime} 2^{\prime \prime}$ N., $11^{\circ}$ W.The trawl was shot at noon in 200 fathoms, but capsized and came up empty. A few specimens of Dorocidaris papillata and some fragments of Brisinga were sticking in the swabs.

Station 4. July 13th. Position, $49^{\circ} 5^{\prime} 40^{\prime \prime}$ N., $11^{\circ} 14^{\prime}$ W. -The trawl was shot in 217 fathoms, and brought up a single large specimen of Lophius piscatorius, half a dozen Rhombus boscii, a single Macrurus lævis, one Solea Greenii, and two small Gadoids. There were, as before numerous specimens of Spatangus purpureus and Holothuria tremula, and a few Dorocidaris papillata. The specimen of Solea Greenii, a female, is considerably larger than that taken by the "Flying Fox," and was perfectly ripe, the ova running out on deck when it was brought on board. When alive its upper surface was of a uniform chestnut-brown colour.

Station 5. July 15th. Position, $48^{\circ} 59^{\prime} 42^{\prime \prime}$ N., $10^{\circ} 7^{\prime} 27^{\prime \prime}$ W. -The trawl was shot twice in ninety fathoms. The first time it capsized and came up empty; the second time it was full, and contained among other things four Rhombus boscii, two small rays, of doubtful position, large numbers of Pecten opercularis, several specimens of Asterias glacialis and A. rubens, Ophiothrix Lütkeni, numerous Polyzoa, chiefly Cellaria and Cellepora; several Hydroids, including some fine specimens of Eudendrium rameum; several colonies of Alcyonium glomeratum, half a dozen specimens of Polythoa incrustata, and a Polythoa which I have not been able to identify satisfactorily.

Station 6. July 16th. Position, $49^{\circ} 23^{\prime} 54^{\prime \prime}$ N., $10^{\circ} 8^{\prime} 34^{\prime \prime}$ W. -The trawl was shot in seventy fathoms on the spot marked in the chart as the "Great Sole Bank." The trawl came up empty, though to judge from the runners it had been working evenly enough. The swabs contained some Ascidians and a Hermione. The trawl was shot a second time a few miles further on $\left(49^{\circ} 26^{\prime} 36^{\prime \prime} \mathrm{N}\right.$., $\left.10^{\circ} 10^{\prime} \mathrm{W}.\right)$, and again was unfortunate, as it capsized and came 
up empty. A few Pycnogonids and many Hydroids and Polyzoa were sticking in the swabs.

Station 7. July 17th. Position, $50^{\circ} 24^{\prime} 45^{\prime \prime}$ N., $10^{\circ} 7^{\prime} 30^{\prime \prime}$ W.The trawl was shot at noon in seventy fathoms, and hauled two hours afterwards. When it came on board a large hole was found to be torn in the cod end, through which much of the contents must have escaped. The catch included among other things a single specimen of Luidia (probably ciliaris), several specimens of Echinus acutus, and a single specimen of Porania pulvillus. Among other Hydroids was a considerable quantity of Tubularia coronata.

Station 8. July 18th. Position, $50^{\circ} 22^{\prime} 21^{\prime \prime}$ N., $10^{\circ} 7^{\prime} 30^{\prime \prime}$ W.The trawl was down for two hours on a gravelly bottom. Depth about seventy fathoms. The contents did not differ much from those of the previous day. A single specimen of Holothuria tremula was taken, and the presence of numerous Ophioglypha albida and Adamsia palliata was the only noticeable feature. A large Actinian, apparently an Actinoloba, was also caught, but it was so much damaged as to be beyond recognition.

The following is a list of all the specimens taken in the trawl and identified. It must be understood that not every specimen was brought home for identification. As I was asked not to bring too much baggage on board, I limited my supply of bottles and spirit, and each day after examining the contents of the trawl, I preserved only such specimens as I could not recognise. Naturally enough, I had afterwards to regret not having preserved many specimens which I identified on board and returned to the sea; but, on the other hand, I am satisfied that my actual collections, together with my notes of species observed on board, give a very nearly accurate account of the fauna as exhibited in our trawling.

\section{VERTEBRATA.-PISCES.}

Raia batis, Linn.

A single large specimen at Station 1, 200 fath. I am not aware that this species has been recorded from so great a depth before. Dr. Günther (Challenger Reports, Deep Sea Fishes, p. 11) says that it has been observed on the Norwegian coast down to 150 fath.

RAIA, sp. incert.

Several specimens of a small ray were obtained at Stations 5 and 6. Being unable to identify them with any described species, I forwarded a specimen to Dr. Günther, who kindly examined it and wrote as follows:- "I cannot identify it with any of the known 
British species ; it comes nearest to Raia circularis and $R$. miraletus (from the Mediterranean), but shows differences in the seutellation form of the body, and ornamental colouring. But it would be hazardous to offer a more definite opinion, as we know very little about the amount of variation and of the changes with growth and locality in rays."

All the specimens taken were apparently young.

\section{Teleostei.-Acanthopterygii.}

Scorpana dactyloptera, De la Roche.

Several specimens in 200 and 217 fath. This species was also taken by Mr. Green, before whose expedition it was unknown to British fauna.

LOPHIUS PISCATORIUS, Linn.

A single large specimen at Station 4, 200 fath. The angler, according to Brown Goode, is known to descend to considerable depths.

CaLLionymus lyra, Linn.

Many specimens, Stations 7 and 8, 70 fath.

\section{Anacanthini.}

GadUS ARgenteus, Guich.

Two specimens at Station 4, 217 fath. This species was first found in the Mediterranean, and has only once been taken since, by the "Porcupine" in 1869, very close to the station at which I obtained it. (See Günther, Ann. Mag. Nat. Hist., xiii, 1874, p. 138.)

Phycis Aldrichit, n. sp.

Two specimens of this genus were obtained at Station 1, from a depth of 200 fath. After careful examination (they are unfortunately a good deal damaged) I cannot identify them with any described species, and therefore propose to name it, provisionally, Phycis Aldrichii, in honour of my host, Capt. Aldrich. This form is very closely allied to $P$. americanus, Schn. (with which it may prove to be identical), differing from it chiefly in the first dorsal, the anterior rays of which are not elongated in P. Aldrichii.

The following is the description of the species: 
D. $10 / 52$. A. 50 .

Length of the head somewhat less than one quarter the total length of the body, excluding the caudal fin. Eye equal in length to the snout. Length of eye rather more than one third the length of the head. Interorbital space less than the height of the eye. Barbel about three quarters the length of the eye. The first dorsal has its origin behind the insertion of the pectoral fin. The third ray of the first dorsal is the longest, but is not as long as the head. Length of the pectoral less than that of the head. Ventrals extend as far back as the third or fourth ray of the anal fin. Vertical and caudal fins edged with black.

The specimens described are $20 \mathrm{~cm}$. long.

Haloporphyrus eques, Günth.

One specimen was obtained at Station 2, 400 fath. New to Great Britain. Numerous specimens were obtained in the Faröe Channel by the " Knight Errant" in 1880 and 1882.

MacruRus celorhynchus, Risso.

Three specimens from Station 1, 200 fath. This species and the following were unknown to British fauna before Mr. Green's expedition.

Macrurus levis, Lowe.

Several specimens from Stations 1 and 4 .

Rhombus boscir, Risso.

Many specimens from Stations 1, 4, and 7. I at first mistook this species for the "megrim," Rhombus megastoma, but the enormous size of the eyes shows it to be $R$. boscii. At Station 1 we trawled nearly a hundred, and ate nearly all of them under the impression that they were megrims. They are very good eating. This, again, is a species found by Mr. Green, and previously new to British fauna.

Arnoglossus laterna, Günth.

Many small specimens from Stations 5 and 7, 70 fath.

Pleuronectes cynoglossus, Limn.

Stations 1 (200 fath.) and 8 (70 fath.).

Dr, Günther, in the "Challenger" report on deep sea fishes, 
notes the remarkable fact that this littoral species is sometimes found at considerable depths. The greatest depth recorded is 732 fath.

Solea Greenir, Günth.

Station 4, 217 fath. I obtained a single specimen of this interesting new species, discovered a week before my cruise by $\mathrm{Mr}$. Green, who also only obtained a single specimen. Mine is a female, larger than the other, being $18.8 \mathrm{~cm}$. in length, and was perfectly ripe when caught, the roe running out on the slightest pressure. When fresh the colour of the upper side was a uniform chestnut brown.

\section{TUNICATA.}

Ascidia virginea, O. F. Müller.

Two specimens adhering to Serpula tubes.

Ascidia fusiformis, Herdman.

Five specimens, adhering to Annelid tubes and Polyzoa, varying in size from three quarters of an inch to an inch and a quarter. The larger individuals contained numerous ova in the peribranchial cavity. These with the preceding species were dredged in 70 fath.

Diplosoma, sp.?

One small colony, attached to a Hydroid stem.

\section{MOLLUSCA.-GASTEROPODA.}

Leptothyra Bournei, Norman.

Vide addendum by Canon Norman, p. 323.

Solarium mediterraneum, Monterosato.

Vide addendum by Canon Norman, p. 322.

Natica nitida.

Station 7, 70 fath.

Calyptrea sinensis, Linn.

Station 7. Several specimens.

Aporrhais pes-Pelecani, Lin $u$.

Shell containing Phascolion strombi from Station 8. 
Aporrhais pes-Carbonis, Brogn.

Station 1, 200 fath.

Morio (Cassidaria) tyrrhena, Chem.

Two fine specimens of this rare Gasteropod were taken at Station 2, 400 fath.

Fusus gracilis, Da Cost.

Several specimens from Station 2.

Scaphander lignarius, Limn.

Several specimens from 70 fath.

\section{Nudibranchiata.}

Archidoris tuberculata, Cuvier.

Two small specimens from Station 8. Mr. Garstang has examined these and finds that they do not differ appreciably from specimens trawled in shallower water near Plymouth.

\section{Cephalopoda.}

Octopus vulgaris, Lamk.

Two small specimens.

Eledone cirrhosa, Lamk.

One young specimen.

\section{Lamellibranchiata.}

Pectunculus glycymeris, Linn.

Several specimens from 70 fath.

Astarte sulcata, $D a$ Cost.

A specimen from Station 2, 400 fath.

Venus casina, Linn.

Station 1, 200 fath. 
Pinna Rudis, Linn.

Several specimens from 70 fath.

Pecten opercularis, Limn.

Common in 70 fath.

Pecten septemradiatus, Müll.

A single specimen from Station 2, 400 fath.

Pecten tigrinus, Müll.

From Station 8, 70 fath.

CRUSTACEA. Decapoda.

Atelecyclus heterodon, Leach.

From 400 and 70 fath.

Portunus tuberculatus, Roux.

A single specimen. Station 7, 70 fath.

Bathynectes longispina, Stimp.

A single specimen of this rare species was taken in 400 fath.

Xantho tuberculatus, Bell.

Station 2, 400 fath.

Anamathia Carpenteri, Norman.

1873. Anamathia Carpenteri, Norman. In Wyville Thomson's Depths of the Sea, p. 175, fig. 35 .

1883. Soyramathin Carpenteri, A. Milne Edwards. Recueil de figures de Crustacés nouveaux ou peu connus, pl. ii.

1885. - $\quad-\quad$ G. O. Sars. Norwegian N. Atlantic Expl. Expedit., 1876-8, Crustacea, p. 6, pl. i, figs. $1-7$.

1886. ANamathia CaRPexteri, S. J. Smith. Rep. Decapoda, "Albatross" Dredgings, p. 21.

Seven specimens from 400 fath.

Canon Norman sends me the following note :-“ Mr. Pocock, in his recent paper on the trawlings of the 'Flying Fox,' says that he is not aware that this species had gained a right to be included in the 
British Fauna; yet the type specimens, one of which was originally described in The Depths of the Sea, were distinctly recorded as having been dredged on the Holtenia ground off the Butt of Lewis."

Inachus dorsetitensis, Penn.

\section{Lispognathus Thomsoni, Norman.}

1873. Dorhynchus Thomsoni, Norman. In Wyville Thomson's Depths of the Sea, p. 174, fig. 34 .

1881. Lispognathus Thomsoni, A. Milne Edwards. Comptes Rendus, pp. 878 and 932.

1883. - - $\quad$ - A. Milne Edwards. Recueil de figures de Crustacés nouveaux ou peu connus, pl. iii.

$1883 . \quad-\quad$ fercatus, Smith. Proc. Nat. Museum U.S., vol, vi, p. 18.

1886. - - Thомroni, Smith. Report Decapoda, "Albatross" Dredging, 1884, p. 18.

A single specimen from 400 fath. This species was also obtained in the "Flying Fox" expedition. Canon Norman sends me the following note:-“This species, like Anamathia Carpenteri, was figured in The Depths of the Sea as one of the inhabitants of the warm area off the Butt of Lewis, yet Mr. Pocock says that he was not aware that it had been recorded as a British species. Moreover, both species were again recorded from the same district in my report of the Crustacea of the 'Knight Errant' Expedition."**

Stenorhynchus tenuirostris, $M$. $E d w$.

Ebalia nux, Norman, MS.

1880. Ebatia xux, Norman. Notes on the French Exploration of "Le Travailleur" in the Bay of Biscay, Am. Mag. Nat. Hist. and Rep. Brit. Assoc., p. 387.

1883. - - (Norman), Marion. Annales du Musée d'Hist. Nat. de Marseille, vol. i, mém. 2, p. 36.

1883. - - (Norman), A. Milne Edwards. Recueil de figures de Crustacés nouveaux ou peu connus, pl. v.

1889. - - Pocock. Am. Mag. Nat. Hist., ser. 6, vol. iv, p. 426.

A single specimen was taken in 400 fath. The single specimen of the "Flying Fox" was taken in 315 fath. Canon Norman sends me the following notes on this species:- "Mr. Pocock seems to have been unaware that Ebalia nux had been admirably figured by Prof. A. Milne Edwards. The following is the distribution of the species as far as is known to me."

“' 'Porcupine,' 1869, Stations 1, 3, 6, 11, all off the west and southwest of Ireland, in 90 to 1630 fath. ; also Station 46 , lat. $59^{\circ} 23^{\prime} \mathrm{N}$.,

* Proc. Royal Soc. Edinb., 1882. 
long. $7^{\circ} 4^{\prime} \mathrm{W}$., that is to the north-west of the Butt of Lewis, on the margin of the Holtenia ground, in 374 fath.

“' Porcupine,' 1870, Station 8, lat. $48^{\circ} 13^{\prime}$ N., long. $9^{\circ} 11^{\prime}$ W., 257 fath.; Station 10, off Cape Finisterre, 91 fath., Vigo Bay ;* Station 13, off Cape Mondego, coast of Portugal, 220 fath.; Station 26, off south coast of Portugal, 364 fath. ; and in the Mediterranean, off Cape de Gatt, 60 to 160 fath., and on the Adventure bank, 92 fath.

"'Travailleur' Expedition, 1880. In this expedition Ebalia nux was taken many times in the Bay of Biscay off the Spanish coast. My notes taken on board give me July 17th, 666 metres; July 23rd, 1107 to 1353 metres.

"'Travailleur,' 1881. In this year's expedition Prof. Milne Edwards reports it as again taken in the Bay of Biscay, and also in the northern part of the Mediterranean, 300 metres.

" 'Flying Fox' and 'Research' trawlings off the south-west coast of Treland. Profs. A. Milne Edwards and Marion courteously recognise my MS. name Ebalia nux, but if that is rejected it will stand as Ebalia nux, A. Milne Edwards."

\section{Parapagurus pilosimanus, Smith.}

1880. Eupagurus JaCoBi, A. Milne Edwards. Études préliminaires sur les Crustacés, Blake Exped. in Bull. Mus. Comp. Zool., viii, p. 42.

Three specimens in old shells covered by Epizanothus paguriphilus, 400 fath. Dr. Norman informs me that the first evidence he had of the existence of this species in the Eastern Atlantic was that of a single arm dredged by the "Triton" Expedition in 1882, Station 13 , lat. $59^{\circ} 51^{\prime}$ N., long. $8^{\circ} 18^{\prime}$ W., in 570 fath. ; and this fragment he was enabled positively to identify by direct comparison with American examples. Its occurrence is now first recorded. He also calls my attention to the fact that the species was in the same year recorded by Prof. Milne Edwards (under the name Eupagurus Jacobi, M. Edw.) as having been dredged off the Spanish coast by the "Travailleur." Thus this recently described deep-sea Pagurid is already known to have a most extensive range-Guadaloupe, St. Lucia, Martinique, N.E. America ; in the British area north-west of the Butt of Lewis and off the south of Ireland, also extending southwards to the coast of Spain.

Eupagurus meticulosus, Roux.

Several specimens in shells covered by Polythoa incrustata in 70 fath.

* So labelled, but probably one of the dredgings off Vigo Bay. 
Eupagurus pubescens, Kröyer.

Eupagurus carneus, Pocock. Ann. Mag. Nat Hist., 6th series, vol. iv, p. 428.

This species was first taken by $\mathrm{Mr}$. Green in the "Flying" Fox." My single specimen, a female, was trawled in 400 fath. It inhabited a large shell of Fusus gracilis.

Galathea nexa, Emb.

Galathea dispersa, Bate.

Munida bamrfica, Pennant.

Stations 7 and 8, 70 fath.

Pontophilus spinosus, Leach.

A single specimen from Station 2, 400 fath.

\section{IsOPODA.}

Aga tridens, Leach.

Single specimen, 200 fath.

\section{AMPHIPODA.*}

Amphithopsis latipes, $M$. Sars.

Metopa Brozelil, Goes.

Ericthonius difformis, $\boldsymbol{M} . \boldsymbol{E} d w$.

Melita obtusata.

Stenothö̈ marina, $S p . B$.

Copepoda.

Artotrogus Bomckir, Brady.

A single specimen, 75 fath.

\section{Pantopoda.}

Pychogondm littorale, Ström.

Several specimens from 200 and 70 fath.

\section{Polychata.}

Hermione Hystrix, Sav.

Three specimens from 400 fath.

* Mr. A. O. Walker has kindly looked through and identified my small collection of Amphipoda.

NEW SERIES.-VOL. I, NO. III. 
Lagisca rarispina, Sars. 70 fath.

Amphitrite cirrata, Müll.

70 fath.

Hyalingcia tubicola, $O, F$. Müll.

70 fath.

Ditrupa ARIETina, Müller.

Amphiporus lacteus?

Nemertea.

Station 7.

Gephyrea.

Phascolion strombi, Théel.

Polyzoa.

Scrupocellaria scruposa, Linn.

Cellaria sinuosa, Hassall.

Cellaria Johnstoni, Busk.

Cellepora ramulosa, Linn.

Cellepora dichotoma, Hincks.

All the Polyzoa were taken in moderate depths (70 fath.).

Anthozoa.

Actinadge Richardi, Marion.

From Stations 1 and 2, 200 and 400 fath.

Chitonactis coronata, Gosse.

Station 1, 200 fath.

Adamsia palliata, Forbes.

Many specimens from Station 8, 70 fath.

Epizonnthus Paguriphilus, Verrill.

Three specimens of this species, which is here recorded for the first time, I believe, from English seas, were obtained at Station 2, 400 fath. They were associated with Parapagurus pilosimanus. Mr. Pocock, in the Report on the Crustacea of Mr. Green's expedi. 
tion, says that the $P$. pilosimanus obtained were associated with an Epizoanthus, but no further mention is made of the latter, which may have been $E$. paguriphilus.

Polythoa incrustata, Sars.

Several specimens from Station 5, 70 fath. Associated with Eupagurus meticulosus.

Polythos, sp. incert.

The difficulty of identifying the species of this genus from spirit specimens is so great that I have given up the attempt in this instance. The specimen obtained was from 90 fath. at Station 5 .

HrdrozoA.

Perigonimus arenaceus?

Growing on a Fucus shell in 200 fath.

Eudendrium rameum, Pall.

Tubularia indivisa, Limn.

Tubularia coronata, Abild.

Diphasia pinaster, Ellis and Sol.

Sertularella Gayi, Lam.

Aglaophenia myriophyllum, $\operatorname{Linn}$.

Antennularia antennina, Flem.

With the exception of Perigonimus, all the Hydroids were trawled from moderate depths.

In addition to the trawling I made frequent use of the tow-net, but was somewhat hampered by the necessities of the cruise. At night we were anchored, and the tides were seldom strong enough to keep my net extended; during the day we were working rapidly along the lines of observation, when tow-netting was impossible, or we were trawling, when it was difficult. I did most of my work during the trawling, but whenever the paddles were moved-and they had to be moved pretty often to keep the ship's head up-I ran the risk of losing my net.

I was anxious to make a comparison between the surface fauna outside Plymouth and that at the entrance to the Channel, in order to settle the question whether there is a current setting in towards the Channel, and carrying the numerous southern and Atlantic forms which are from time to time taken on the south-west coast in an easterly direction. Such a current, if it existed, would be a part of 
Reynell's current, but in fact it does not exist except as a surface current, due to prevalent westerly winds. This was shown both by the daily observations of Captain Aldrich with current logs, and by the contents of the tow-net. The current log showed that the tides cause a rotatory current moving in the same direction as the hands of a watch, and there is a tendency for the rotating stream to move very slowly eastward. The observations were still in progress when I left the ship, and will be published in another place by Captain Aldrich.

The surface fauna was quite different from anything that I have seen in the Channel. Going from Plymouth to Cork, we passed through shoals of Aurelia, but on our stations in the eleventh meridian W. not a single Aurelia was to be seen. On July 12th we passed through a shoal, miles in extent, of Pelagia perla, Haeckel, a form which I have never seen near Plymouth, and which is only at rare intervals cast ashore at Mount's Bay. Each day the net was full of Salpa democratica-mucronata, Forskäl, a form which I have never met with during two summers at Plymouth; and Doliolum Ehrenbergii, Krohn, of which only a few isolated individuals are to be found near Plymouth. Of the Copepoda certain ubiquitous species were plentiful enough (Cetochilus septentrionalis, Clausia elongata, Dias longiremis, Centropages typicus, Oithona spinirostris, and Corycæus anglicus), but more oceanic conditions were indicated by the relatively greater abundance of the first named. I obtained also a large number of Ectinosoma atlanticum, Brady and Robertson, a form which I have never seen in the neighbourhood of Plymouth. In addition to these I took two specimens of Oncæa, which I am satisfied belong to Oncæa obtusa, Dana, as figured by Brady in the "Challenger" Reports, and not to 0 . mediterranea, Claus, which I found near Plymouth in 1889.

The common oceanic Phyllopods Podon and Evadne occurred in great numbers, as also did Hyperia galba, Mont.; and there were a few Zoëa and Megalopa stages of Decapods, but these were far less numerous than in seas nearer land. Tomopteris was fairly common, but Sagitta was far less abundant than in the seas near Plymouth. On one occasion I obtained several very large Bipinnaria larvæ and several later stages in Asterid development. Together with these were Holothurian larvæ (probably of H. tremula), the tailed larvæ of Doliolum, and a single specimen of Tornaria Krohnii, a species which I had previously taken near Plymouth.

Of the Anthomedusæ the species common near the English shores, such as Obelia, Lizzia, and Thaumantias, were entirely absent, but on two occasions I captured large numbers of a very fragile and peculiar Medusa, of which I have been unable to determine the 
relations. It seems to be entirely destitute of either a manubrium or radial canals. A few specimens of Arachnactis albida, a form not uncommon at Plymouth, were taken in each catch.

Of Siphonophora I only obtained two species. One, a Monophysid which is sometimes found at Plymouth, seems to be Muggiæa (Diphyes) Kochii, Will.; the other is an Anthophysid. The latter broke into fragments in the process of preservation, and I cannot determine its species with accuracy. The palpons bear distinct conical eye-spots, which would point to its being a near ally of, if not identical with the Athorybia ocellata of Haeckel. I have never seen a member of the Anthophysidæ in the neighbourhood of Plymouth.

The absence of pelagic Radiolaria at Plymouth has often engaged my attention. In the "Research" I found the following wellknown species in tolerable abundance:-Thalassicolla nucleata, Huxley; Collosphæra Huxleyi, J. Müller; Sphærozoum punctatum, J. Müller; Acanthometron elasticum, Haeckel. In addition to these were several species of Ceratium.

It is apparent from the foregoing that the surface fauna at the entrance to the Channel has a distinct facies, and is different from that nearer the shores of England. A more extended investigation of the surface fauna from the Channel to the Atlantic would probably yield some very interesting results. It may be found that many oceanic species are carried up in mid-Channel, as they are certainly cast ashore in some seasons near Brighton. I have noticed at Plymouth that there is generally a considerable difference between the shore tide and the Channel tide, the latter of which runs three hours later than the former. The Channel tide is almost invariably richer both in amount and variety of pelagic life. There is every reason to believe that the movements of mackerel and pilchards are largely influenced by the distribution of the pelagic fauna, and in proportion as we obtain a more extended knowledge of the latter we may expect to learn more of the still mysterious migrations of these fishes. During the cruise we saw on two or three occasions shoals of fish at a little distance from the ship; probably they were mackerel which were feeding on the abundant surface fauna. The sea, also, was full of the ova and larvæ of Teleostei. Most of the larvæ were Gadoids, but of what species it is impossible to say. Without a much more extended knowledge of facts it is impossible to assert anything about the relations of fishes and surface fauna, but it seems at least reasonable to suppose that the winter pilchards which strike on the south coast of Cornwall, fat and in excellent condition, have come from the rich feeding-ground afforded by the set of the Gulf Stream into the Bay of Biscay. 
Addendum by the Rev. Canon Norman, D.C.L., F.L.S.

Solarium mediterraneum, Monterosato.

1873. Solarium Meditbrranedm, Monterosato. Notizie intorno ai Solarii del Mediterraneo, p. 6, figs. 8, 9 .

A single living specimen dredged in 400 fath., $50^{\circ} 29^{\prime} 26^{\prime \prime} \mathrm{N}$., $11^{\circ} 4^{\prime} \mathrm{W}$.

In his "Porcupine" paper Jeffreys considers Monterosato's species to be a variety of S.pseudo-perspectivum, Brocchi (S. discus, Philippi). It may be so, but I prefer to retain Monterosato's name here because it indicates that the first specimen taken in the British seas is referable to that particular form. It is distinguished from $S$. pseudoperspectivum as follows: The comparative height is somewhat greater, the umbilicus more contracted, the periphery more acutely keeled, and the mouth consequently more pointedly produced in the position of that keel. The upper surface is much smoother, presenting little trace of sculpture beyond a faint spiral line (the corrugated ribs of pseudo-perspectivum being absent); this under surface, on the other hand, is more sculptured, the exterior half of the whorl bearing about ten fine riblets, of which the outer two show some signs of corrugation. Height $7 \mathrm{~mm}$., width $12 \mathrm{~mm}$.

This is a second species of this genus added to our fauna. Two living specimens of Solarium siculum, Cantraine, were dredged by the "Porcupine," 1869 , lat. $51^{\circ} 1^{\prime}$ N., long. $11^{\circ} 21^{\prime}$ W., in 458 fath.

The Mediterranean specimens with which I have compared the Irish specimen of $S$. mediterraneum are accurately represented by Philippi's figure of S. discus ; but Brocchi's figure of S. pseudoperspectivum represents a shell of which the upper surface is smooth or nearly so, and in this respect like $S$. mediterraneum, but it wants the riblets of the under surface characteristic of the latter form.

\section{Family TURBINID丑.}

Gemus Leprothyra, P. P. Carpenter, MS. (Dall, 1871) = Collonia, Philippi (non Collonia, Gray, 1852) = Homalopoma, P. P. Carpenter, 1864 = Leptonyx, P. P. Carpenter, 1864 (non Leptonyx, Swain, 1821).

Dall, in his Report on the "Blake" Mollusca (Bull. Soc. Comp. Zool., xviii, p. 352), by a slip of memory says in a note, "The name Homalopoma was under consideration by Dr. Carpenter as a substitute for Leptonyx, but was never published by him." The fact is that Homalopoma was the first term used by him (Supp. Report 
Mollusca West Coast of North America, in Brit. Assoc. Rep., 1863, p. 537); but at a subsequent page (652), when he characterises the genus, he substitutes the name Leptonyx, adding " genus = Homalopoma, p. 537, nom. preoc." I cannot find that this name has been used, but as no description was given under the name Homalopoma it may perhaps be best to retain the name which has been adopted by Dall.

\section{Leptothyra Bournei, n. sp.}

Shell shortly conical, whorls six, girt (except at the base) with numerous thread-like riblets, one of which is a little more prominent than the rest, and forms a keel; on the body-whorl there are six riblets below and three above the more prominent riblet; on the penultimate whorl there are four below and four above; no transverse-that is, vertical sculpture; apex rather blunt. Base convex, without any trace of umbilicus or umbilical chink. Shell very solid. Pillar lip slightly longitudinally channelled, the channel interrupted in the middle by a transverse depressed nodule. Colour white; interior of shell and umbilical region highly polished and nacreous with fine prismatic colouring. Operculum calcareous ; external surface minutely granulated, rather sunken centrally, exhibiting no trace of spiral arrangement; internal surface chitinous, with central nucleus and multispiral $(11-12)$ whorls, the outermost whorl rapidly enlarging. Lingual membranes have the lateral uncini extremely numerous, hamate ; central teeth hamate, ten in number.* Length $18 \mathrm{~mm}$., breadth $20 \mathrm{~mm}$.

A single living specimen was dredged in 200 fath., $50^{\circ} 50^{\prime} 15^{\prime \prime} \mathrm{N}$., $11^{\circ} 12^{\prime} 30^{\prime \prime} \mathrm{W}$.

This is a fine shell, and the largest species known of the genus; its operculum closely agrees in character with that of the type ( $L$. sanguinea, Linn.).

From L. induta, Watson (Report "Challenger" Gasteropoda, p. 128, pl. vi, fig. 1), it differs in the more shortly conical form, and in the total absence of the longitudinal " infra-sutural puckerings" "and beaded riblets of the upper whorls; while, on the other hand, the spiral sculpture of the present form is much more developed. It comes much nearer to the shell described by Dall (l. c., p. 352, pl. xxxviii, fig. 6) as Leptothyra induta, var. albida, but in that case the riblets are fewer in number but much more pronounced; and it may, I think, be questioned whether Dall's variety is really referable to Watson's species.

* The mounting is not very good, but I am unable to discover the usual central tooth. In that position there seems to be a gap, on either side of which are five teeth. 